\title{
THE IMPACT OF GLYCO-METABOLIC STATUS IN PATIENTS TREATED FOR ACUTE CORONARY SYNDROME
}

\author{
Marija Vavlukis, Biljana Zafirovska, Emilija Antova, Bekim Pocesta, Enes Shehu, Hajber Taravari, \\ Irena Kotlar, Darko Kitanovski, Danica Petkoska, Ivan Vasilev, Filip Janusevski, Ivica Bojovski, Sashko Kedev
}

University Clinic of Cardiology, Medical Faculty, Ss. Cyril and Methodius University, Skopje, Republic of Macedonia

Corresponding author: Prof. d-r Sasko Kedev, MD, PhD, FESC, FACC, University Clinic of Cardiology, St. Mother Theresa 17, 1000, Skopje, Ss. Cyril and Methodius University, Medical Faculty, Skopje, Republic of Macedonia, e-mail: skedev@gmail.com, Cell: 0038970226552, Fax: 0038923113116

\section{ABSTRACT}

Objective: The aim of the study was to assess the prevalence of newly diagnosed diabetes in patients with acute coronary syndrome and estimate the relationship between stress hyperglycemia, glyco-regulation and newly diagnosed diabetes with hospital morbidity and mortality.

Methods: This was an observational study which included all patients hospitalized due to acute coronary syndrome (January 2015 until April 2017) at the University Clinic of Cardiology in Skopje, Macedonia. We analyzed demographic, clinical, biochemical variables and hospital morbidity and mortality. Five investigated groups were compared using a single biochemical parameter glycated hemoglobin (HgbAlc) depending on the presence of known diabetes before the acute event: 0 -without DM (HgbA1c $<5.6 \%)$, 1-newly diagnosed pre-diabetes (HgbA1c 5.6-6.5\%), 2-newly diagnosed diabetes (HgbA1c $\geq 6.5 \%)$, 3-known well controlled diabetes (HgbA1c <7\%) and 4-known un-controlled diabetes (HgbA1c $\geq 7 \%$ ).

Results: 860 patients were analyzed. Impaired glucose metabolism was confirmed in $35 \%$ of patients, $9 \%$ of which were with newly diagnosed diabetes. Stress hyperglycemia was reported in $27.3 \%(3.6 \%$ were without diabetes). The highest values of stress hyperglycemia were reported in newly diagnosed and known un-controlled diabetes. In-hospital morbidity and mortality were $15 \%$ and $5 \%$ accordingly and the rate was highest in patients with newly diagnosed and known, but un-controlled diabetes. HgbA1c, stress hyperglycemia, and poor glycemic control have emerged as significant independent predictors of hospital morbidity and mortality in patients with acute coronary syndrome.

Conclusion: High prevalence of newly diagnosed diabetes was observed in patients with acute coronary syndrome. Stress hyperglycemia and failure to achieve glycemic control are independent predictors of hospital morbidity and mortality.

Keywords: acute coronary syndrome, diabetes mellitus, newly diagnosed diabetes mellitus, stress glycaemia, hospital morbidity, hospital mortality.

\section{INTRODUCTION}

An increasing prevalence of diabetes mellitus is observed on global level, currently estimated at around $12-14 \%$, due to an increasing incidence, but also due to prolonged survival (longevity of diabetic patients) caused by improved diabetes care. Increasing trends are projected over the years to come, especially in the Middle East, India, China, Japan, etc. [1] Middle Eastern countries and Saudi Arabia are among those with the highest diabetes prevalence (23.7\% in Saudi Arabia), and in the same time the highest prevalence of diabetes mellitus in the population of patients with Acute 
Coronary Syndrome (ACS). [2] Caucasians have significantly lower rates of incidence of diabetes. In the study of Lugg et al. the reported prevalence of pre-diabetes was $14.3 \%$ and diabetes $10.8 \%$ in patients treated for ACS in England. Similar data have been reported by Arnold and his coworkers $[10 \%$ prevalence of newly diagnosed diabetes in patients with acute myocardial infarction (AMI), previously not known to have diabetes]. [3]

Stress hyperglycemia is present in one of four hospitalized patients. In the Study by Gardner et al., stress hyperglycemia was found in $41 \%$ of elderly patients with ACS. The three possible causes for hyperglycemia in patients hospitalized due to ACS are existing known diabetes, existing but unknown diabetes and stress hyperglycemia. According to the definition of The American Diabetes Association (ADA), stress hyperglycemia is an elevation of fasting glucose $\geq 7 \mathrm{mmol} / \mathrm{L}$, or 2-hour postprandial glucose $\geq 11 \mathrm{mmol} / \mathrm{L}$, in a patient without previous diabetes mellitus. Glycated hemoglobin ( $\mathrm{HbAlc}$ ) measurement is recommended for making distinction between patients with stress hyperglycemia and patients with previously undiagnosed diabetes. HbA1c value $\geq 6.5 \%$ indicates pre-existing unrecognized diabetes, whereas $\mathrm{HbA} 1 \mathrm{c}$ value $<6.5 \%$ indicates stress-induced hyperglycemia. [1, 4] OGTT (oral glycose tolerance test) is recommended as a second line test for patients with stress hyperglycemia, once normal $\mathrm{HbA} 1 \mathrm{c}$ is confirmed, as this subgroup of patients are at increased risk of future diabetes development. [5]

\section{The impact of hyperglycemia}

Diabetic patients have a more severe risk profile; more often present with NSTEMI, have a more diffuse atherosclerotic disease, and carry a higher risk of complications, nearly doubled in comparison to non-diabetics. [2] But, now, we are aware that stress hyperglycemia is an even more powerful predictor, either in patients with previously known diabetes, or patients not known to be diabetics before the index event. Patients with stress hyperglycemia present with a higher mortality rate and longer hospitalization time in comparison to patients with known diabetes and with normoglycaemia. Non-diabetic patients with stress hyperglycemia have 3.9 fold higher risk of death after myocardial infarction in comparison to normoglycaemic non-DM patients. [3, 6, 7]

Having all this in mind, we decided to perform a more comprehensive analysis of our pa- tients' cohort hospitalized and treated for Acute Coronary Syndrome, in terms of incidence of stress hyperglycemia and newly diagnosed diabetes, but also to determine the prognostic impact of glyco-metabolic parameters on short term (in-hospital) clinical outcome in these patients' cohort.

\section{MATERIALS AND METHODS}

This was a longitudinal observational study. Patients admitted to ICCU and treated for acute coronary syndrome (ACS): unstable angina (APNS), myocardial infarction without ST-segment elevation (NSTEMI) and myocardial infarction with ST-segment elevation (STEMI) were enrolled. We used data from the STEMI Registry at the University Clinic of Cardiology in Skopje, Republic of Macedonia, for patients receiving treatment during the period January 2015 - April 2017. We analyzed parameters of glyco-metabolic state: blood glycose (BG) level at admission (stress glycemia), fasting plasma glycose (FPG), random BG levels and HgbAlc. We also analyzed demographic variables: age and gender; clinical variables: cardiovascular (CV) risk factors, previous medical history of coronary artery disease (CAD): previous MI, myocardial revascularization with percutany coronary intervention or aorto-coronary bypass surgery), co-morbidities; disease characteristics: type and location of the myocardial infarction, extent and severity of the coronary artery disease (as expressed by SINTAX score, TIMI flow before and after PCI procedure), and myocardial contractile function, expressed via ejection fraction (EF \%); biochemical variables: hemogram, BUN, creatinine, biomarkers of myocardial injury (CPK, CK-MB, LDH, myoglobin, HsTn), lipoprotein fractions [TG, CHOL, HDL-C, LDL-C, $1 \mathrm{p}(\mathrm{a})]$; variables that determine the glyco-metabolic state during hospital treatment: stress glycemia, glyco-regulation during hospital treatment and glycolized hemoglobin; duration of hospitalization (days) and in-hospital morbidity and mortality.

Patients were divided in five groups according to the presence of known diabetes and HbA1c:

0-patients without DM (non-DM) with $\mathrm{HbA} 1 \mathrm{c}<5.6 \%$; 
1-patients with pre-diabetes (pre-DM) with $\mathrm{HbA1c} 5.6-6.5 \%$;

2-patients with newly-diagnosed diabetes (NDDM) with $\mathrm{HbA} 1 \mathrm{c} \geq 6.5 \%$;

3-patients with known diabetes well controlled (WCDM) with $\mathrm{HbA} 1 \mathrm{c}<7 \%$; and

4-patients with known diabetes purely controlled (UCDM) with HbA1c $\geq 7 \%$ ).

For the definition of diabetes, we used criteria defined by The American Diabetes Association (ADA) Guidelines from 2015: fasting plasma glycose $(\mathrm{FPG})>7 \mathrm{mmol} / \mathrm{L}$, or random plasma glucose $(\mathrm{RPG})>11.1 \mathrm{mmol} / \mathrm{L}$, or $\mathrm{HgbA} 1 \mathrm{Cc}$ $>6.5 \%$, and $\mathrm{HgbA} 1 \mathrm{c}$ between $5.6 \%-6.5 \%$ for the definition of pre-diabetes. The criteria used to define stress hyperglycemia included: an elevation of FPG $\geq 7 \mathrm{mmol} / \mathrm{L}$, or $\mathrm{RPG} \geq 11 \mathrm{mmol} / \mathrm{L}$ in a patient without evidence of previous diabetes. For distinction between patients with stress hyperglycemia and newly diagnosed diabetes we used the glycated hemoglobin value (HbAlc value $\geq 6.5 \%$ indicating pre-existing unrecognized diabetes, whereas HbA1c value $<6.5 \%$ indicating stress-induced hyperglycemia). Also, we used the ADA recommendations for controlled diabetes (HgbAlc $<7 \%$ ), to distinguish diabetic patients with well controlled as opposite to purely controlled diabetes. For glyco-regulation status determination we also used the ADA glycemic target for critically ill patients $(6.1-10 \mathrm{mmol} / \mathrm{L})$. These are different from recommendations given in the ESC STEMI Guidelines from 2017 considering glycemic control, where the lower limit is set to $3.9 \mathrm{mmol} / \mathrm{L}$ (that is the definition of hypoglycemia). If a patient was in this range during hospitalization we defined that as a good glycemic control, as opposite to those patients in whom we failed to achieve this target, that were classified as hypoglycemic (if episodes of hypoglycemia were registered during hospitalization), or hyperglycemic if episodes of hyperglycemia were registered. We performed a comparative analysis between all patients belonging to the five different glyco-metabolic states.

\section{Statistical Methods}

IBM SPSS statistics' software version 22 was used for statistical analysis. Descriptive: frequencies, means, medians, ranges, standard deviation, as well as categorical variables: absolute numbers and percentages were described. The
ANOVA test was used to analyze differences in continuous variables inside the group and PostHoc multiple comparison with the Tukey test for comparison between groups. When needed non-parametric tests were obtained. The Pearson Chi square test was used for categorical variables (Pearson Chi square) and the Fisher exact test for $2 \times 2$ tables, and Odds Ratio (with CI) and Mantel-Haenszel common odds ratio estimation was performed. For determination of predictors, univariate and multivariate linear (for continuous independent variable) and/or binary logistic regression analysis was performed. For the most significant variables ROC curves were obtained. Significance was determined at the level of 0.05 .

\section{RESULTS}

A total of 860 patients, treated for Acute Coronary Syndrome at the University Clinic of Cardiology in Skopje, Republic of Macedonia were analyzed. Two thirds of the patients included in the study were males $590(69 \%)$ and 270 $(31 \%)$ were females $(p=0.000)$. Mean age was $63.8 \pm 11.5$ years, with a very homogenous age distribution, which can be observed by the same median (63) and mode age (63), with skewness to the right $(-.131 \pm 0.083 \mathrm{SE})$, but there was a significant gender difference in age distribution, with males being significantly younger, $62.6 \pm 11.3$ versus $65.6 \pm 11.6$ for females $(\mathrm{p}=0.0001)$, with a mean age difference of 3.05 years.

Graph 1. Patient distribution by age (left), and by age across the two genders (right)

Analysis was made based on the glyco-metabolic patient status, divided into five groups, and the patient distribution was as follows: $35.9 \%$ were non-DM patients, high proportion of patients $-35 \%$ not known to have glycol-metabolic disturbances were found to be pre-DM patients $26 \%$, and $9 \%$ were newly-diagnosed DM patients. $29.1 \%$ of patients were with known diabetes, but according to HbA1c level, $14.9 \%$ had WCDM and $14.2 \%$ had UCDM (Chi square test parametric and non-parametric $p=0.000$, and $p=0.046$ for gender distribution across glyco-metabolic groups found with non-parametric test, while $\mathrm{p}=\mathrm{ns}$ found with the Pearson chi-square test). 

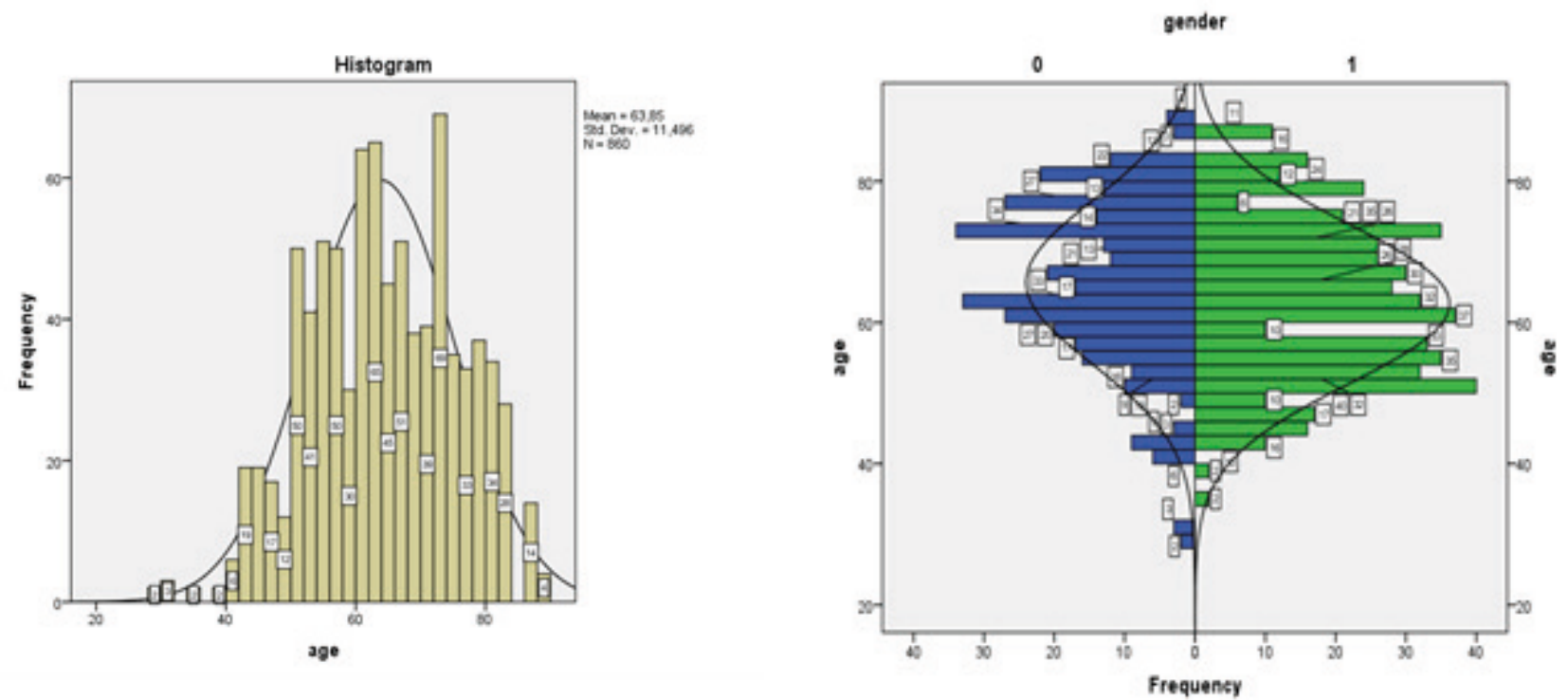

Graph 1. Patient distribution by age (left), and by age across the two genders (right)

Legend 0-female; 1-male

Graph 2. Patient distribution across the five compared groups and both genders

Mean values of blood glycose measured at hospital admission - stress glycemia and glycated hemoglobin levels are presented in Table 1. The highest values were measured in NDDM and UCDM. Stress hyperglycemia was present in $27.3 \%$ of all ACS patients, half of them being in the UCDM group. But, what is even more important, 3.6\% of patients in the non-DM group, $15.3 \%$ in the pre-DM, and $67.9 \%$ in the NDDM had stress hyperglycemia $(\mathrm{p}=0.000)$.

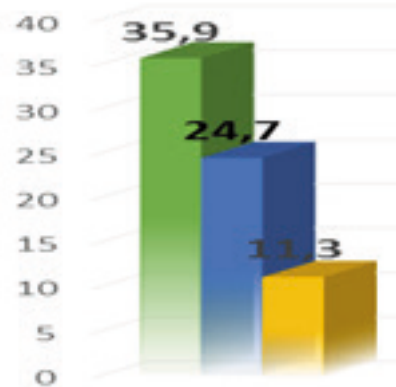

o

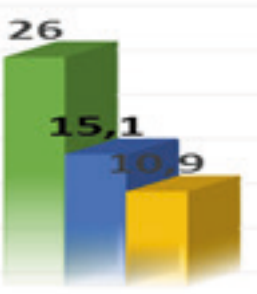

1

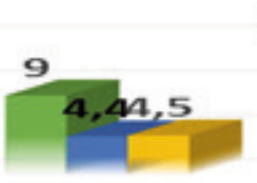

2

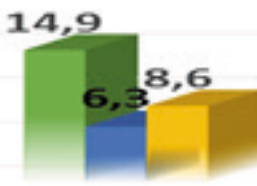

3

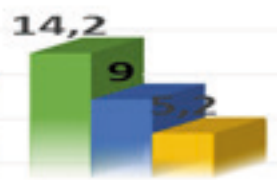

4

- Total - males - females

Graph 2. Patient distribution across the five compared groups and both genders

Legend: 0:non-DM; 1:pre-DM; 2:NDDM; 3:WCDM; 4:UCDM; Values expressed as percentages of total $N$ 
Table 1. Glycemia on admission and glycated hemoglobin across the compared groups

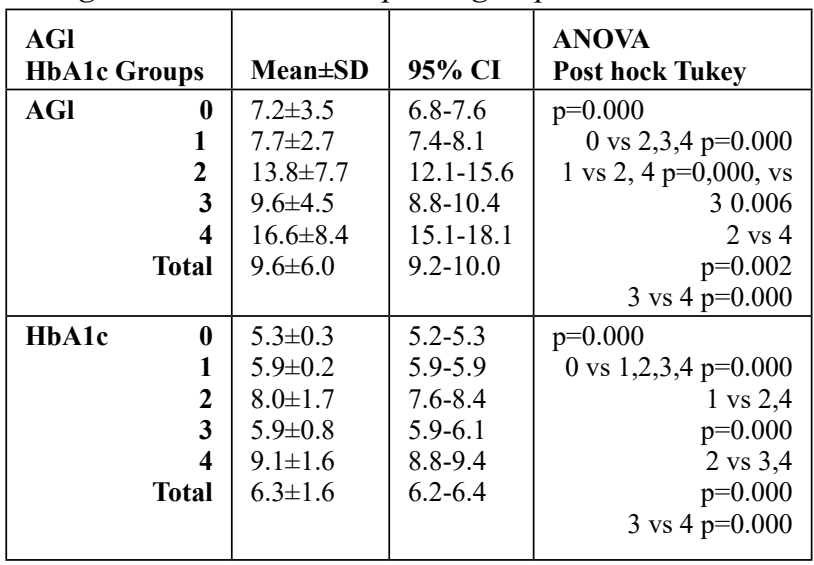

Legend: AGl-glycemia at admission; HbAlc-glycated hemoglobin;

Most patients were STEMI patients (75.7\%), with no statistically significant difference across compared groups. NSTEMI predominated in patients with newly-diagnosed
DM (14.7\%) and APNS in patients with known diabetes. As expected, arterial hypertension presented as a predominate risk factor, especially in DM patients, with two thirds of the patients being hypertensive; known hyper/dyslipidemia was also more present in diabetic patients: $30.5 \%$ and $25.4 \%$ respectively in the WCDM and UCDM groups $(p=0.060)$, although measured LP fractions expressed true means above the recommended values in all compared groups (Table 2). $37.6 \%$ of patients were smokers, with the lowest rate observed in patients with well controlled $\mathrm{DM}$, in which group the highest percentage of former smokers was observed (19.5\%). Systolic dysfunction during index event was observed in $46.9 \%$ of patients, significantly higher in newly-diagnosed and known-diabetic patients, compared to the other groups $(p=0.000)$. By far, the most severe risk profile was observed in newly-diagnosed diabetics. Clinical characteristics of the study group in total and within the five compared groups are presented on Table 2.

Table 2. Clinical characteristics of the patients in total, and across the five different glyco-metabolic status groups

\begin{tabular}{|c|c|c|c|c|c|c|c|}
\hline VARIABLE & Total & GROUP 0 & GROUP 1 & GROUP 2 & GROUP 3 & GROUP 4 & p value \\
\hline $\begin{array}{lc}\text { Gender } & 0(\mathrm{f}) \\
\text { \% within } & 1(\mathrm{~m}) \\
\text { the var.) } & \text { all }\end{array}$ & $\begin{array}{l}31 \\
69 \\
100\end{array}$ & $\begin{array}{l}39.9 \\
48.9 \\
45.3\end{array}$ & $\begin{array}{l}23.9 \\
23.4 \\
23.6\end{array}$ & $\begin{array}{l}\mathbf{8 . 0} \\
4.9 \\
6.2\end{array}$ & $\begin{array}{l}\mathbf{1 2 . 1} \\
4.9 \\
7.8\end{array}$ & $\begin{array}{l}16.1 \\
17.9 \\
17.2\end{array}$ & 0.000 \\
\hline Age & $63.8 \pm 11.0$ & $61.8 \pm 12.4$ & $66.1 \pm 10.8$ & $64.4 \pm 9.5$ & $65.9 \pm 9.3$ & $64.8 \pm 10.7$ & 0.000 \\
\hline $\begin{array}{rr}\text { Dg } & \text { STEMI } \\
\text { NSTEMI } \\
\text { APNS }\end{array}$ & $\begin{array}{l}75.7 \\
10.9 \\
13.4\end{array}$ & $\begin{array}{l}74.8 \\
11.7 \\
13.5\end{array}$ & $\begin{array}{l}\mathbf{7 2 . 8} \\
\mathbf{1 4 . 7} \\
12.5\end{array}$ & $\begin{array}{l}81.8 \\
7.8 \\
10.4\end{array}$ & $\begin{array}{l}77.2 \\
6.3 \\
\mathbf{1 6 . 5}\end{array}$ & $\begin{array}{l}77.9 \\
9.0 \\
\mathbf{1 3 . 1}\end{array}$ & ns \\
\hline HTA (\% within the gr.) & 56.2 & 48.4 & 58.1 & 50.6 & 65.6 & 66.4 & 0.001 \\
\hline HLP $(\%)$ & 22.5 & 18.1 & 26.6 & 10.4 & 30.5 & 25.4 & 0.060 \\
\hline Family history (\%) & 28.1 & 19.2 & 27.9 & 42.9 & 34.9 & 34.4 & 0.000 \\
\hline Known DM (\%) & 29.1 & & & & 14.9 & 14.2 & 0.006 \\
\hline $\begin{array}{r}\text { Smoking active } \\
\text { former }\end{array}$ & $\begin{array}{l}37.6 \\
5.4\end{array}$ & $\begin{array}{l}47.9 \\
4.5\end{array}$ & $\begin{array}{l}34.1 \\
0.9\end{array}$ & $\begin{array}{l}26.0 \\
0\end{array}$ & $\begin{array}{l}25.0 \\
19.5\end{array}$ & $\begin{array}{l}38.5 \\
4.1\end{array}$ & 0.000 \\
\hline HCAD $(\%)$ & 24.4 & 20.7 & 24.1 & 39.0 & 24.7 & 19.7 & 0.006 \\
\hline $\mathbf{E F}<\mathbf{5 0 \%}$ (\% of pts) & 46.9 & 43.6 & 34.9 & 65.6 & 50.5 & 62.6 & 0.000 \\
\hline $\mathbf{H b}(m g / d l)$ & $14.1 \pm 1.9$ & $14.2 \pm 1.5$ & $14.1 \pm 1.9$ & $13.2 \pm 2.2$ & $14.3 \pm 1.6$ & $13.8 \pm 2.7$ & 0.000 \\
\hline BUN $(\mathrm{mmol} / \mathrm{L})$ & $6.8 \pm 3.8$ & $6.1 \pm 2.9$ & $6.8 \pm 4.1$ & $8.9 \pm 4.4$ & $6.6 \pm 3.2$ & $7.4 \pm 5.1$ & 0.000 \\
\hline Creatinine $(\mu \mathrm{moll} / \mathrm{L})$ & $92.8 \pm 63.5$ & $82.3 \pm 33.3$ & $92.2 \pm 49.3$ & $100.1 \pm 36.7$ & $113.9 \pm 127.9$ & $92.4 \pm 47.8$ & 0.002 \\
\hline
\end{tabular}

Legend: STEMI-ST-segment elevation myocardial infarction; NSTEMI-non-ST-segment elevation myocardial infarction; APNS-unstable angina; HTA-arterial hypertension; HLP-hyperlipidemia; DM-diabetes mellitus; HCAD-chronic coronary artery disease; EF-ejection fraction; Hb-hemoglobin; BUN-blood urea 
Although only $22.5 \%$ of patients reported hyperlipidemia, hyper/dyslipidemia was present across all compared groups, as expressed by means. TG were the highest in NDDM and UCDM, while in the same time UCDM had the lowest HDL-C levels. (Table 3)

Table 3. LP values across different glyco-metabolic groups

\begin{tabular}{|c|c|c|c|c|c|c|}
\hline $\mathbf{L P}$ & $\begin{array}{l}\text { HbA1c } \\
\text { group }\end{array}$ & $\begin{array}{l}\mathbf{T g} \\
(\mathrm{moll} / \mathrm{L})\end{array}$ & CHOL $(\mathrm{moll} / \mathrm{L})$ & $\begin{array}{l}\text { HDL-C } \\
(\mathrm{moll} / \mathrm{L})\end{array}$ & $\begin{array}{l}\text { LDL-C } \\
(\mathrm{moll} / \mathrm{L})\end{array}$ & $\begin{array}{l}\mathbf{L p}(\mathbf{a})(m g / \\
d l)\end{array}$ \\
\hline Mean \pm SD & $\begin{array}{r}0 \\
1 \\
2 \\
3 \\
4 \\
\text { Total }\end{array}$ & $\begin{array}{l}1.7 \pm 0.9 \\
1.7 \pm 1.1 \\
2.7 \pm 2.4 \\
1.8 \pm 0.9 \\
2.2 \pm 1.2 \\
1.9 \pm 1.2\end{array}$ & $\begin{array}{l}5.2 \pm 1.4 \\
5.6 \pm 1.5 \\
5.7 \pm 1.1 \\
5.5 \pm 1.4 \\
5.3 \pm 1.5 \\
5.4 \pm 1.4\end{array}$ & $\begin{array}{l}1.2 \pm 0.4 \\
1.2 \pm 0.4 \\
1.2 \pm 0.3 \\
1.2 \pm 0.6 \\
1.0 \pm 0.3 \\
1.2 \pm 0.4\end{array}$ & $\begin{array}{l}3.2 \pm 1.2 \\
3.5 \pm 1.3 \\
3.5 \pm 1.0 \\
3.5 \pm 1.1 \\
3.4 \pm 1.3 \\
3.4 \pm 1.2\end{array}$ & $\begin{array}{l}33.7 \pm 27.9 \\
29.5 \pm 26.1 \\
40.8 \pm 54.6 \\
33.6 \pm 19.9 \\
42.6 \pm 39.3 \\
34.5 \pm 31.0\end{array}$ \\
\hline $\begin{array}{l}\text { 95\% Confidence } \\
\text { Interval for Mean }\end{array}$ & $\begin{array}{r}0 \\
1 \\
2 \\
3 \\
4 \\
\text { Total } \\
\end{array}$ & $\begin{array}{l}1.5-1.8 \\
1.6-1.9 \\
2.1-3.3 \\
1.7-2.0 \\
1.9-2.4 \\
1.8-1.9\end{array}$ & $\begin{array}{l}4.9-5.4 \\
5.4-5.8 \\
5.4-5.9 \\
5.2-5.7 \\
4.9-5.6 \\
5.3-5.5\end{array}$ & $\begin{array}{l}1.1-1.2 \\
1.2-1.3 \\
1.1-1.2 \\
1.1-1.3 \\
0.9-1.1 \\
1.1-1.2\end{array}$ & $\begin{array}{l}3.0-3.4 \\
3.3-3.7 \\
3.2-3.7 \\
3.3-3.7 \\
3.1-3.6 \\
3.3-3.5\end{array}$ & $\begin{array}{l}28.8-38.5 \\
24.6-34.5 \\
15.3-66.4 \\
27.8-39.4 \\
33.1-52.2 \\
31.3-37.6\end{array}$ \\
\hline ANOVA & & 0.000 & 0.012 & 0.005 & 0.082 & 0.076 \\
\hline Post hock Tukey & & $\begin{array}{r}0.1 \text { vs } 2,2 \text { vs } 3 p=0.000 \\
0 \text { vs } 4 \mathrm{p}=0.008 \\
1 \text { vs } 4 \mathrm{p}=0.057 \\
2 \text { vs } 4 \mathrm{p}=0.019\end{array}$ & 0 vs $1 \mathrm{p}=0.021$ & & & $\begin{array}{r}1 \text { vs } 4 \\
p=0.049\end{array}$ \\
\hline
\end{tabular}

Legend: LP-lipoprotein; TG-triglyceride; CHOL-cholesterol; HDL-C-high density lipoprotein; LDL-C-low density lipoprotein cholesterol; Lp(a)- lipoprotein (a)

As previously mentioned, disease severity was analyzed with LVEF and SINTAX score. Patients with NDDM and UCDM had worse LV systolic function, significantly lower in comparison to non-DM patients. The same was observed regarding the extent and severity of CAD. More severe CAD was observed in NDDM and UCDM patients. There was a significant difference in the known DM groups as a function of glycose control. Patients with WCDM presented with the same disease severity as non-DM and pre-DM patients (Table 4). The same finding was obtained regarding hospitalization length, which was significantly longer in NDDM, as compared to the other groups. In-hospital morbidity was observed in $129(15 \%)$ patients, 43 $(5 \%)$ of whom presented with a fatal outcome. The highest event rate was observed in non-DM and UCDM patients, and the same finding was obtained for in-hospital mortality. 
Table 4. Disease severity/ length of hospitalization and outcome across the different glycol-metabolic groups

\begin{tabular}{|c|c|c|c|}
\hline $\begin{array}{l}\text { Variable } \\
\text { HbA1c Groups }\end{array}$ & Mean \pm SD & 95\% CI for Mean & $\begin{array}{l}\text { ANOVA } \\
\text { Post hock Tukey }\end{array}$ \\
\hline $\begin{array}{r}\mathbf{0} \\
\mathbf{1} \\
\mathbf{2} \\
\mathbf{3} \\
\mathbf{4} \\
\text { Total }\end{array}$ & $\begin{array}{l}52.0 \pm 9.1 \\
52.9 \pm 8.3 \\
49.6 \pm 9.6 \\
52.4 \pm 8.9 \\
49.2 \pm 8.1 \\
51.6 \pm 8.7\end{array}$ & $\begin{array}{l}50.9-53.1 \\
51.7-54.1 \\
47.1-52.0 \\
50.6-54.2 \\
47.7-50.8 \\
51.0-52.3\end{array}$ & $\begin{array}{l}p=0.002 \\
0 \text { vs } 4 p=0.042 \\
1 \text { vs } 4 p=0.005\end{array}$ \\
\hline $\begin{array}{lr}\text { SINTAX score } & 0 \\
& 1 \\
& 2 \\
& 3 \\
& 4 \\
& \text { Total }\end{array}$ & $\begin{array}{l}14.5 \pm 8.6 \\
14.6 \pm 7.6 \\
16.4 \pm 8.1 \\
14.4 \pm 7.9 \\
18.1 \pm 7.2 \\
15.2 \pm 7.9\end{array}$ & $\begin{array}{l}13.2-15.2 \\
13.3-15.6 \\
13.9-18.8 \\
12.7-16.0 \\
16.4-19.5 \\
14.5-15.8\end{array}$ & $\begin{array}{l}p=0.004 \\
0 \text { vs } 4 p=0.004 \\
1 \text { vs } 4 p=0.012 \\
3 \text { vs } 4 p=0.018\end{array}$ \\
\hline $\begin{array}{lrr}\text { Length of } & 0 & \\
\text { hospitalization } & 1 & 2 \\
& & 3 \\
& & 4 \\
& & \text { Total }\end{array}$ & $\begin{array}{l}4.3 \pm 2.1 \\
4.1 \pm 2.1 \\
5.3 \pm 3.2 \\
4.1 \pm 1.8 \\
4.7 \pm 3.5 \\
4.3 \pm 2.5\end{array}$ & $\begin{array}{l}4.1-4.5 \\
3.8-4.3 \\
4.6-6.0 \\
3.8-4.4 \\
4.0-5.3 \\
4.2-4.5\end{array}$ & $\begin{array}{l}p=0.001 \\
0 \text { vs } 2 p=0.011 \\
1 \text { vs } 2 p=0.001 \\
2 \text { vs } 3 p=0.005\end{array}$ \\
\hline 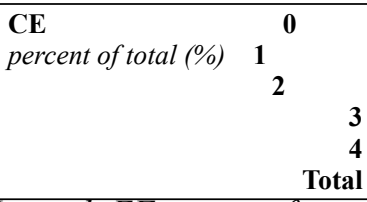 & $\begin{array}{l}4.2 \\
2.6 \\
2.0 \\
2.0 \\
4.2 \\
\mathbf{1 5 . 0}\end{array}$ & $\begin{array}{ll}\text { CD } & 1.5 \\
& 0.7 \\
& 0.8 \\
& 0.2 \\
& 1.8 \\
& \mathbf{5 . 0} \\
& \end{array}$ & $\begin{array}{l}\text { for } C E p=0.000 \\
\text { for } C D p=0.000\end{array}$ \\
\hline
\end{tabular}

Legend: EF-ejection fraction; CE-in-hospital morbidity; CD-in-hospital mortality;

A significant positive correlation was found between admitting glycaemia and in-hospital event rate, with a correlation coefficient of $r=.266 ; p=0.000$ for in-hospital morbidity, and $r=.216 ; p=0.000$ for in-hospital mortality, with significance at the level of 0.001

Graph 3. Correlation of glycaemia at admission with in-hospital morbidity/mortality

Another important glyco-metabolic status parameter is blood glucose level during hospital treatment. In our study population, $73.7 \%$ of patients were with regulated blood glycose level, in $6.5 \%$ of patients hypoglycemic episodes were registered $(\mathrm{Gl} \leq 3.9 \mathrm{mmol} / \mathrm{L})$, while $19.8 \%$ presented with hyperglycemic episodes (Gl $\geq 11.1 \mathrm{mmol} / \mathrm{L}$ ). The highest event rate was seen in patients who failed to achieve glycemic control, and experienced hyperglycemic episodes. These patients had 3.066 odds ratio for in-hospital morbidity (CI 2,083-4,514) Mantel Haenszel OR estimate $\mathrm{p}=0.000$, and 4.243 odds ratio for in-hospital mortality (CI 2,2286-7,938) Mantel Haenszel OR estimate $\mathrm{p}=0.000$, as compared to patients with regulated blood glycose.

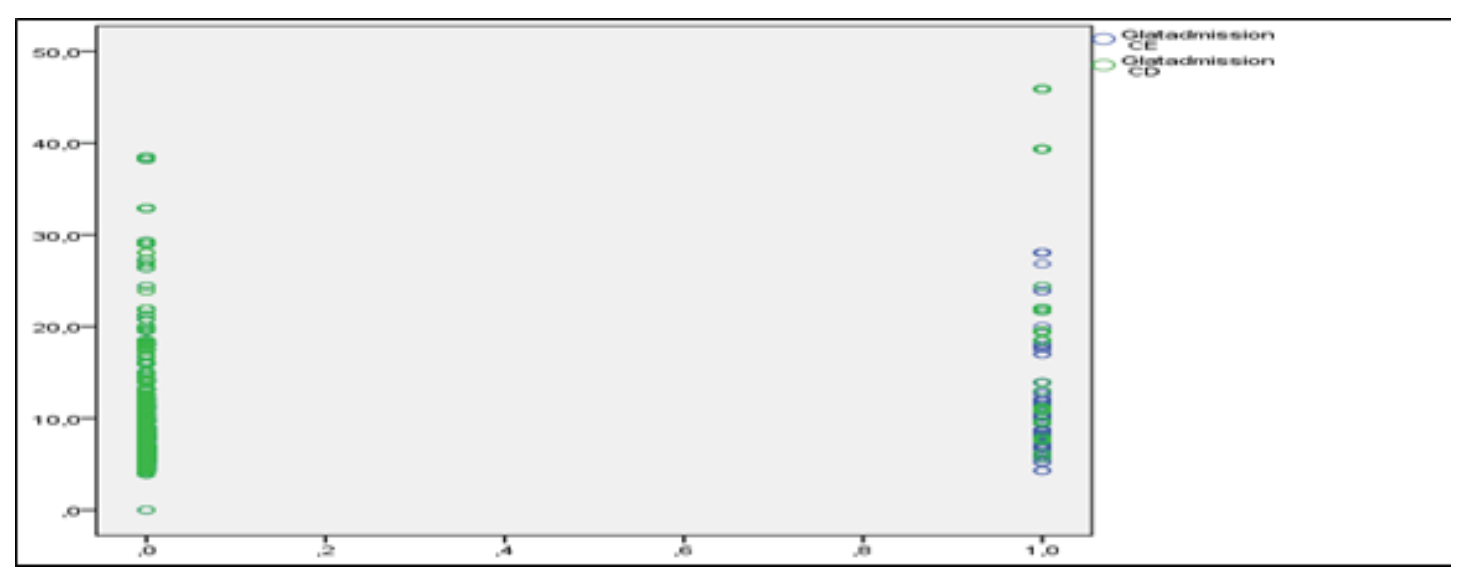

Graph 3. Correlation of glycemia at admission with in-hospital morbidity/mortality

Legend: CE-in-hospital morbidity; CD-in-hospital mortality 
Graph 4. Distribution of cardiac events (in-hospital morbidity and mortality) across three glyco-regulated states

We aimed to determine the role of glyco-metabolic status in patients with ACS on early in-hospital outcome. We identified multiple variables that were associated with in-hospital morbidity and mortality, and with a binary logistic regression analysis (backward conditional), we identified several independent predictors.
In the model with Chi square 98.862, sig 0.000, percent of prediction correct $87.4 \%$, stress hyperglycemia was a significant independent predictor of in-hospital morbidity, while in the model with Chi square 113.084, sig 0.000, percent of prediction correct $96.2 \%$, stress hyperglycemia, glycated hemoglobin and hyperglycemic episodes were identified as independent predictors of in-hospital mortality.

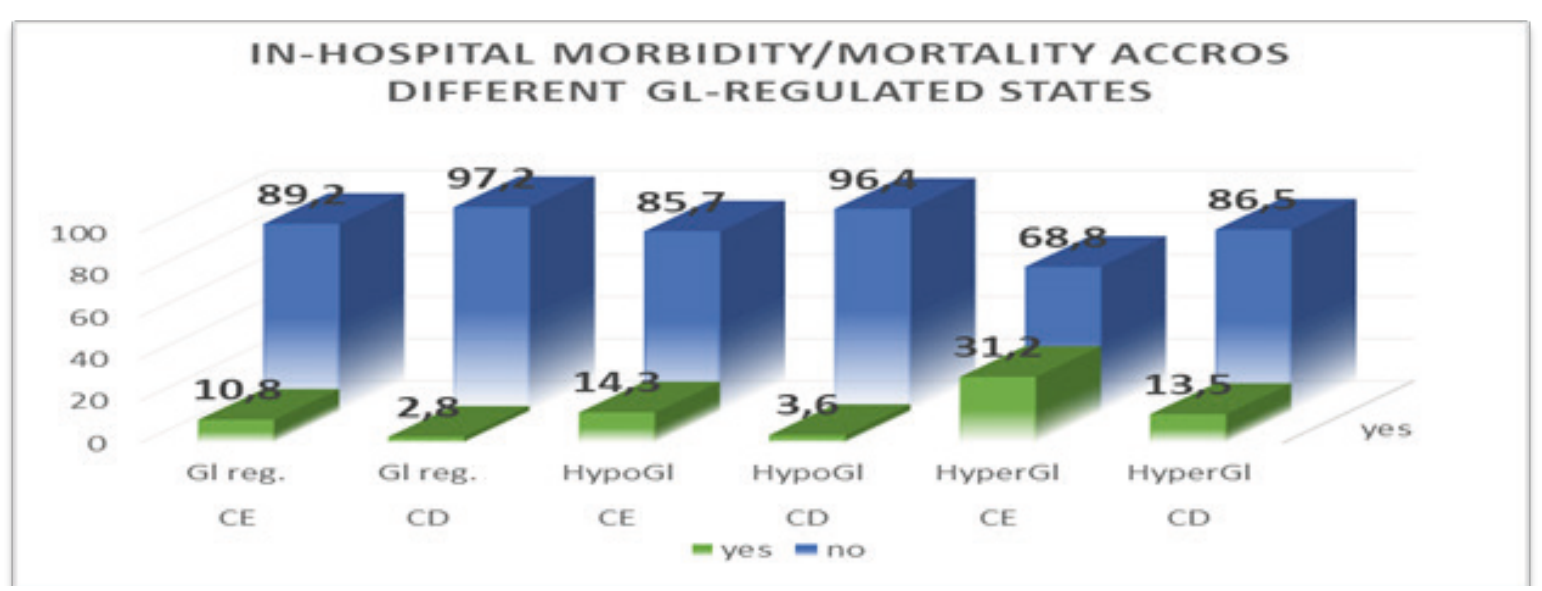

Graph 4. Distribution of cardiac events (in-hospital morbidity and mortality) across three glyco-regulated states

Legend: CE-cardiac events (in-hospital morbidity); CD-cardiac death (in-hospital mortality); Values are expressed as percentages, with $100 \%$ being the number of patients in the group

Table 5. Independent predictors of in-hospital morbidity/ in-hospital mortality

\begin{tabular}{|l|l|l|l|l|l|l|}
\hline In-hospital morbidity & & & & & & \\
\hline Variable & B & S.E. & Wald & Sig. & Exp(B) & 95\% CI for EXP(B) \\
\hline Dg. NSTEMI & 2.212 & .830 & 7.099 & .008 & 9.130 & $1.795-46.451$ \\
EF <50\% & 1.112 & .445 & 6.249 & .021 & 3.040 & $1.271-7.267$ \\
Stress hyperglycemia & -1.392 & .290 & 22.991 & .000 & .249 & $.141-.439$ \\
Age & .049 & .013 & 14.638 & .000 & 1.050 & $1.024-1.077$ \\
EF (\%) & -.115 & .027 & 18.239 & .000 & .892 & $.846-.940$ \\
Constant & -4.717 & 1.833 & 6.623 & .010 & .009 & \\
\hline In-hospital mortality & & & & & & \\
\hline Variable & $\mathbf{B}$ & S.E. & Wald & Sig. & Exp(B) & $\mathbf{9 5 \%}$ CI for EXP(B) \\
\hline Hyper (Gl. regulation) & 1.540 & .828 & 3.457 & .063 & 9.130 & $.920-23.651$ \\
Hb & -.389 & .082 & 22.703 & .000 & 3.040 & .249 \\
HbA1c & -.536 & .193 & 7.663 & .006 & $.2578-.796$ \\
Stress hyperglycemia & .228 & .045 & 25.547 & .000 & 1.256 \\
EF (\%) & -.129 & .027 & 23.528 & .000 & .879 \\
Constant & 8.865 & 2.096 & 17.892 & .000 & 7080.456 \\
\hline
\end{tabular}

Stress hyperglycemia appears to be a strong independent predictor of early disease course in ACS treated patients. The classification of performance capability of stress glycaemia was for in-hospital morbidity, as presented with a ROC curve with an area under the curve of 0.714 (CI 0.666-761) and $p=0.000$, and for in-hospital mortality with an area under the curve of 0.783 (CI 0.712-0.853) and $p=0.000$ (Graph 5a and 5b). 

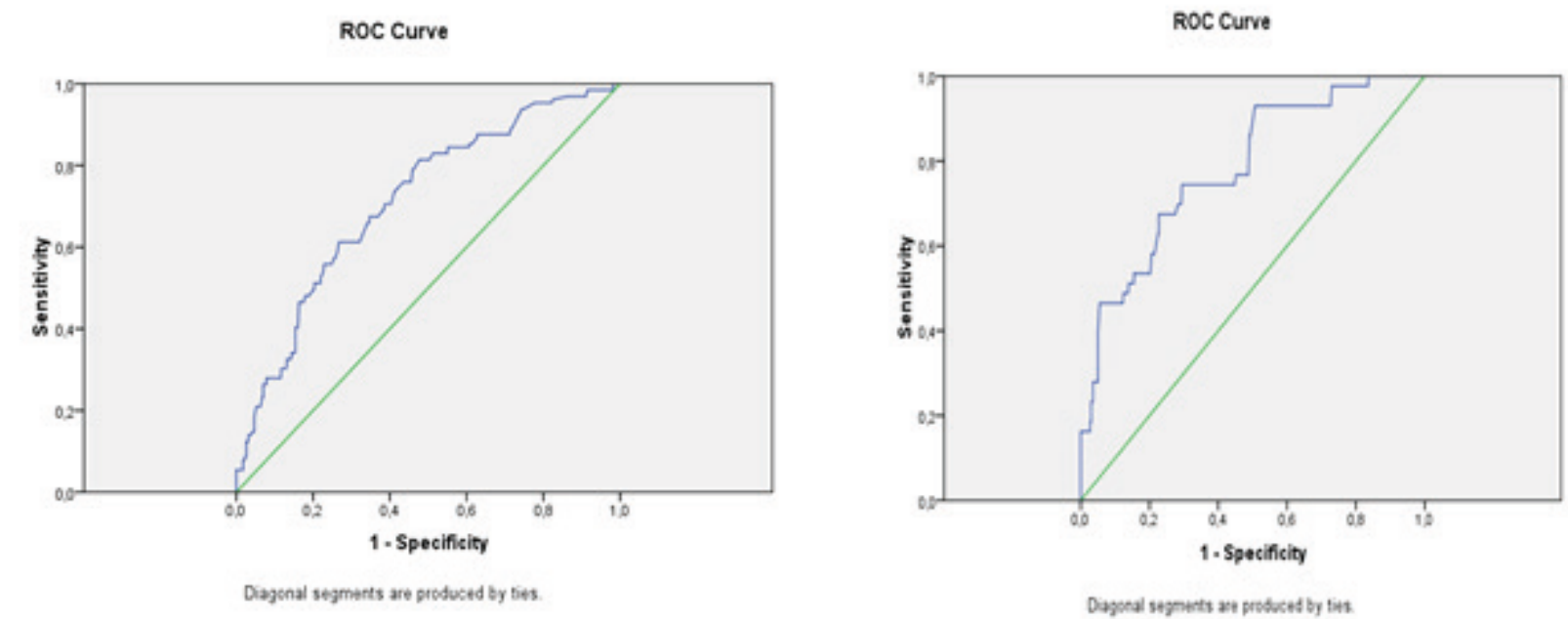

Graph 5a/5b. Predictive role of stress hyperglycemia in in-hospital morbidity and mortality

\section{DISCUSSION}

Incidence of newly diagnosed diabetes and stress hyperglycemia

There is significant diversity in the incidence of newly diagnosed diabetes and stress hyperglycemia in patients treated for Acute Coronary Syndrome across the globe. (Graph 6) also presented with a very high prevalence of NDDM (21\%), pre-diabetes (14\%), and stress hyperglycemia $(10 \%)$, in predominantly male and elderly patients, as reported by Abdullatef et al. [1] Even when living in European settings, patients of South Asian ethnicity, as reported by Lugg et al., are at higher risk of developing T2DM. There is a significant body of accumulated evidence considering: Asian Indians, Afro-Caribbean, Hispanic and Asian ethnicity,

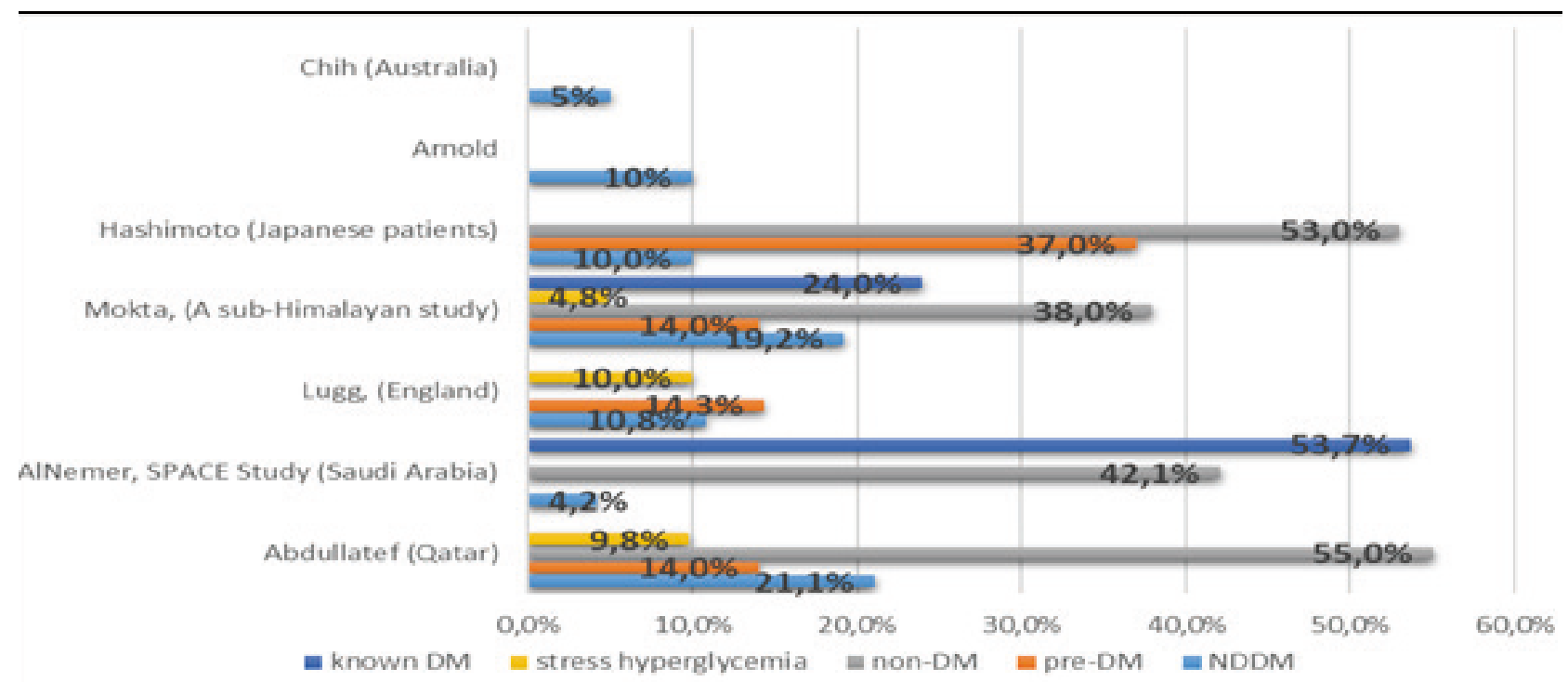

Graph 6. Incidence of newly diagnosed diabetes and stress hyperglycemia (graph generated by the authors).

As recorded in The Saudi Project for Acute Coronary Events (SPACE) registry, $57.9 \%$ of patients with Acute Coronary Syndrome had diabetes $(92.8 \%$ known diabetes, and 7.2\% newly diagnosed). This is by far the highest diabetes prevalence ever reported in an ACS population. [2] Another middle east ACS population (Qatar) who, in comparison to Caucasians, demonstrate a higher prevalence of hyperglycemia following ACS. In the same ethnic groups, the concentration of HbAlc is also higher, as compared to Caucasian patients with similar plasma glucose levels. [3] Lugg and coworkers reported a prevalence of pre-diabetes of $14.3 \%$ and T2DM 
of $10.8 \%$ in patients treated for ACS in England. Arnold reported similar data - 10\% prevalence of T2DM in AMI patients without known diabetes on admission. [3] Maybe the lowest prevalence of NDDM is reported by Chin in an Australian cohort of ACS patients, about 5\%. [1] It is evident that there is a significant influence of racial affiliation on the prevalence of diabetes in the general population, and in the cohort of patients with ACS. However, at this moment, we do not have enough evidence to state that the severity and type of acute coronary syndrome affects the incidence of pre-diabetes and diabetes. [3]

Stress hyperglycemia is even more important than newly diagnosed diabetes in terms of prognosis in ACS patients. It is reported that one in every four hospitalized critically ill patients has stress hyperglycemia. In the study of Gardner, admission hyperglycemia was found in $41 \%$ of the elderly patients with acute coronary syndrome. Causes for hyperglycemia in hospitalized patients are existing known diabetes, existing but unknown diabetes, and stress hyperglycemia. Stress hyperglycemia is defined by ADA (and the criteria were described previously in this manuscript). [3]

In our cohort of patients, stress hyperglycemia was present in $27.3 \%$ of ACS patients, half of them in the group of patients with known but uncontrolled diabetes. Also, the highest levels of blood glycose at admission were registered in this group, as well as in the newly diagnosed diabetes group (16.6 \pm 8.4 and $13.8 \pm 7.7$ respectively, $\mathrm{p}=0.000)$.

Recommendations for monitoring and treatment for hyperglycemia and/or diabetes in patients with ACS

In terms of diabetes monitoring in patients with ACS, ESC Guidelines for the Management of AMI STEMI (2017), recommend evaluation of the glycemic status in all patients, with or without a history of DM or hyperglycemia, and frequent monitoring of glycaemia in diabetic patients and patients with admitting hyperglycemia (BG level $\geq 11.1 \mathrm{mmol} / \mathrm{L}$ ) (Class I, LOE C). [9]

In terms of treatment of diabetes and/ or hyperglycemia, due to higher risk of hypoglycemia - related events when using intensive insulin therapy, the best approach is a close, but not too strict glycose control. In the acute phase, maintaining a blood glycose concentra- tion $\leq 11.0 \mathrm{mmol} / \mathrm{L}$, and avoiding hypoglycemia $(\leq 3.9 \mathrm{mmol} / \mathrm{L})$, with an indication threshold for glycose-lowering therapy set at $\mathrm{BG}>10 \mathrm{mmol} / \mathrm{L}$ (Class IIa, LOE C) is recommended. [9]

The 2011 NICE Guidelines recommend treatment with dose-adjusted insulin infusion in cases of glycose level $>11.1 \mathrm{mmol} / \mathrm{L}$, with regular monitoring of blood glycose levels. However, some degree of individual approach is recommended, with allowance of less stringent glycose control for ACS patients with more advanced $\mathrm{CVD}$, older age, longer diabetes duration and more comorbidities (Class IIa, LOE C). [10]

The impact of hyperglycemia and NDDM on short- and long-term prognosis of ACS patients

Diabetic patients have a more severe cardiovascular risk profile, are more likely to present with NSTEMI, more often have multi-vessel disease and are at higher risk of complications such as heart failure, repeated revascularization and death. The odds ratio for such outcomes is nearly doubled in comparison to non-diabetics (OR 1.83 (95\% CI, 1.02-3.30, p=0.042). [2] Patients with diabetes have a two-fold higher risk of mortality as compared to non-diabetic patients. The introduction and implementation of the reperfusion therapeutic strategy in patients with ACS, led to an increased survival during the index event in diabetics, but made them prone to significantly increased mortality after 6 months. (4) They do not differ from their non-diabetic pears treated for ACS with respect to the reperfusion and antithrombotic therapy, but in terms of antiplatelet agents, the more potent oral P2Y12 receptor inhibitors (prasugrel or ticagrelor) have been shown to have greater relative benefit, with higher absolute risk reductions, compared to clopidogrel in the diabetic cohort of ACS patients. [9]

Indeed, our cohort of patients with known diabetes had the most severe risk profile and disease severity in terms of more widespread coronary artery disease. Patients with uncontrolled diabetes had the most severe CAD, followed by patients with NDDM (18.1 and 16.4 mean SINTAX score), significantly different from patients without DM, pre-DM, and what is of great importance patients with known well controlled diabetes ( $\mathrm{p}=0.004 ; 0.012 ; 0.018$ respectively). The same results were observed considering the left ventricular systolic function at the time of the 
index event. EF was significantly lower in the UCDM and NDDM (49.2\% and 49.6\% $\mathrm{p}=\mathrm{ns})$, and patients with known uncontrolled and newly diagnosed diabetes had significantly lower EF as compared to NDM and pre-DM patients $(p=0.042$ and 0.005 respectively). On the other side, there was no significant difference compared to patients with well controlled diabetes. The length of hospitalization was significantly longer in patients with NDDM as compared to the other groups $(0.011 ; 0.001 ; 0.005)$, except for UCDM (Table 4).

Patients with DM had odds ratio for in-hospital morbidity of 1.899 (CI 1.291-2.792, $\mathrm{p}=0.001)$ as compared to non-diabetics, and odds ratio for in-hospital mortality of 1.591 (CI .847$2.986, p=0.101)$, meaning that there is no significant difference. However, comparison across the five compared groups demonstrated progressive increase of in-hospital cardiac events/ death, across the groups with impaired glycol-regulation (Table 4).

However, not only diabetes per se, but less established, is the fact that stress hyperglycemia carries an increased risk of complications, not only in diabetic but also in patients with previously unknown diabetes. [1] Elevated plasma glucose levels on admission are very common in patients with MI, and are associated with a high incidence of adverse clinical outcomes. [4] Patients with stress hyperglycemia with no previous history of diabetes have worse clinical outcomes compared to those with pre-existing diabetes with a comparable degree of hyperglycemia. Hyperglycemia is an even more significant predictor of complications in comparison to diabetes per se. Patients with stress hyperglycemia have a higher mortality rate and longer hospitalization time in comparison to patients with known diabetes but who are normo-glycemic. Their risk of death after AMI is 3.9-fold higher compared to normo-glycemic non-diabetic patients. Simon and co-workers reported a positive linear association between the degree of hyperglycemia and mortality in patients with ACS, independent of the presence of confirmed diabetes. Hyperglycemia at the time of hospital admission predicts increased mortality in patients with ACS. [1, 11, 12]. The occurrence of complications is associated with stress hyperglycemia and failure to achieve good glycemic control during hospitalization, not with the presence of diabetes. The impact of hyperglycemia on the clinical outcome depends on several factors such as the intensity of hyperglycemic response, the underlying disease, the co-morbidities, the caloric intake and the risk of infection. [1] The authors of this article reported that stress hyperglycemia is more pronounced in newly diagnosed diabetics, as compared to patients with well controlled known diabetes. [1]

Our study also demonstrated that stress glycemia and glyco-metabolic status are better predictors of in-hospital disease course as compared to diabetes per se. As recorded, the highest event rate was registered in patients who failed to achieve glycemic control and experienced hyperglycemic episodes, who had 3.066 odds ratio for in-hospital morbidity (CI 2.083-4.514; $\mathrm{p}=0.000$ ), and 4.243 odds ratio for in-hospital mortality (CI 2.2286-7.938; p=0.000), as presented in our results (Graph 3).

When identification of predictors of in-hospital morbidity and mortality was conducted, amongst well-established predictors such as age, LV systolic function and NSTEMI type of myocardial infarction, stress glycaemia was identified as an independent predictor for in-hospital morbidity $(\mathrm{p}=0.000)$, and far more significant variables of the glyco-metabolic status were found to be predictors of in-hospital mortality: glyco-regulation, or registered hyperglycemic episodes $(p=0.063), \mathrm{HbA1c}(\mathrm{p}=0.006)$ and stress glycaemia $(p=0.000)$. Stress glycaemia significantly affects the in-hospital course of the disease as demonstrated with correlation coefficients and ROC curves (Graphs 4 and 5a/b).

There is a significant body of evidence for long term prognostic significance of impaired glycose tolerance (IGT) and NDDM in patients who survived ACS. Both conditions are found to be associated with increased long-term morbidity in post-MI patients. However, there is no difference in the MACE rates between the NDDM/IGM and DM groups during long-term follow-up after AMI. The lowest rate of MACE is observed in the group with normal glycemic control. [4] The Diabetes Epidemiology: Collaborative Analysis of Diagnostic Criteria in Europe study, demonstrated that fasting BG alone is not sensitive enough to identify individuals who are at increased risk of death and CV events after index event. They reported that the oral glycose tolerance test provides additional prognostic information. They found that post-challenge hyperglycemia is associated with an increased 
risk of CAD. The Funagata Diabetes Study, in a Japanese cohort of patients with ACS, demonstrated that impaired glycose tolerance, but not impaired fasting plasma glycose, is a risk factor for CV events. According to Tamita, an abnormal OGTT is a better risk predictor of future adverse $\mathrm{CV}$ events than impaired fasting $\mathrm{BG}$ in post MI patients. [4] The study of George et al., also demonstrated that NDDM and IGT (the second one detected with OGTT), are independent predictors of post-MI prognosis. In this study, event-free survival was lower in the IGT and NDDM groups (HR 1.54, 95\% CI: 1.06-2.24, p $=0.024)$ as compared to the pre-DM (HR 2.15, $95 \%$ CI: $1.42-3.24, p=0.003)$ group. Non-infarct related artery revascularization was found to be the most frequent MACE in post-MI patients with NDDM/IGT. The revascularization rate reported by George et al. was like the one reported in the GRACE registry. [6]

\section{LIMITATIONS OF THE STUDY}

This study only follows patients with Acute Coronary Syndrome during their hospital course of treatment. But in the era of reperfusion therapeutic strategies it is well known that in-hospital mortality is very low. The worst outcome is expected during the first year after the index event, a period that we did not address in this study, which can be considered as a limitation to our study.

\section{ONE FITS ALL - Do we need a new concept?}

As confirmed, the relationship between glycose control and outcome is different in patients with and without DM, and in diabetic patients with different glycose control, duration of diabetes etc. Present guidelines for the glycose control in patients with ACS are uniform in terms of recommended blood glycose level. But, the study of Krinsley et al., gives us a different perspective, which probably should and would be applied in the cohort of ACS patients also.

\section{Future directions}

We most certainly need prospective interventional trials, in the cohort of patients treated for ACS that will assess the clinical outcome in patients randomized to personalized glycose targets as a function of their glyco-metabolic status before the index event.

\section{CONCLUSION}

We observed a relatively high prevalence of newly diagnosed diabetes and pre-diabetes, and stress hyperglycemia among patients treated for Acute Coronary Syndrome.

Stress hyperglycemia, HbAlc and failure to achieve good glycose control during the in-hospital course of treatment, are strong independent predictors of in-hospital morbidity and mortality.

\section{Conflict of Interest}

We declare no conflict of interest for this manuscript.

\section{Authors Contributions}

All authors contributed to the designing of the study, drafting, executing, writing and revision of the manuscript.

\section{Acknowledgements}

This study is a part of the Grant received from The Macedonian Academy for Arts and Sciences.

\section{REFERENCES}

1. Kamceva G, Vavlukis M, Kitanoski D, Kedev S. Newly Diagnosed Diabetes and Stress Glycaemia and Its' Association with Acute Coronary Syndrome. Open Access Maced J Med Sci 2015; 3(4): 607-12.

2. AlNemer KA. Important high light on diabetes in acute coronary syndrome cases: Saudi Arabia. Integrative Molecular Medicine 2016; Volume 3(2): 562-3.

3. Lugg ST, May CJK, Nightingale P, et al. HbAlc screening for new onset diabetes following acute coronary syndrome: is it a worthwhile test in clinical practice? Journal of Diabetes \& Metabolic Disorders 2017; 16: 14.

4. Tamita K, Katayama M, Takagi T, et al. Newly diagnosed glucose intolerance and prognosis after acute myocardial infarction: comparison of post-challenge versus fasting glucose concentrations. Heart 2012; 98(11): 848-54.

5. Lazzeri $\mathrm{C}$, Valente $\mathrm{S}$, Chiostri $\mathrm{M}$, et al. Clinical significance of glycated hemoglobin in the acute 
phase of ST elevation myocardial infarction. World J Cardiol. 2014; 6(4): 140-7.

6. George A, Bhatia RT, Buchanan GL, et al. Impaired Glucose Tolerance or Newly Diagnosed Diabetes Mellitus Diagnosed during Admission Adversely Affects Prognosis after Myocardial Infarction: An Observational Study. PLoS ONE 2015; 10(11): e0142045

7. Krinsley JS, Preiser JC, Hirsch IB. Safety and Efficacy of Personalized Glycemic Control in Critically Ill Patients. A 2-Year Before and After Interventional Trial. Endocr Pract. 2017; 23(3): 318-30.

8. Angeli F, Verdecchia P, Karthikeyan G, et al. New-onset hyperglycemia and acute coronary syndrome: a systematic overview and meta-analysis. Curr Diabetes Rev. 2010; 6(2): 102-10.

9. Ibanez B, James S, Agewall S, Antunes MJ, et al. 2017 ESC Guidelines for the management of acute myocardial infarction in patients present- ing with ST-segment elevation: The Task Force for the management of acute myocardial infarction in patients presenting with ST-segment elevation of the European Society of Cardiology (ESC). European Heart Journal, ehx393, https:// doi.org/10.1093/eurheartj/ehx393

10. Hyperglycemia in acute coronary syndromes: management. NICE Clinical guideline [CG130] Published date: October 2011. https://www.nice. org.uk/guidance/cg130

11. Wei CH, Litwin SE. Hyperglycemia and Adverse Outcomes in Acute Coronary Syndromes: Is Serum Glucose the Provocateur or Innocent Bystander? Diabetes 2014; 63(7): 2209-12.

12. Chiang FT, Shyu KG, Wu CJ, et al. Predictors of 1 -year outcomes in the Taiwan Acute Coronary Syndrome Full Spectrum Registry. Journal of the Formosan Medical Association 2014; Vol 113 (11): 794-802. 


\section{Резиме}

\section{ВЛИЈАНИЕТО НА ГЛИКО-МЕТАБОЛНИОТ СТАТУС КАЈ ПАЦИЕНТИТЕ СО АКУТЕН КОРОНАРЕН СИНДРОМ}

Марија Вавлукис, Биљана Зафировска, Емилија Антова, Беким Поцеста, Енес Шеху, Хајбер Таравари, Ирена Котлар, Дарко Китановски, Даница Петкоска, Иван Василев, Филип Јанушевски, Ивица Бојовски, Сашко Кедев

Универзитетска клиника за кардиологија, Медицински факултет, Универзитет „Св. Кирил и Методиј“, Скопје, Република Македонија

Историја: Дијабетесот се дијагностицира кај 10-20\% од пациентите со акутен коронарен синдром (AKC) кои немале познат дијабетес до тој момент. Гликолизаниот хемоглобин, стресхипергликемијата, како и состојбата на гликозна контрола се независни фактори на ризик за хоспиталниот морбидитет и морталитет, без оглед на присуството или отсуството на дијабетес.

Цел: Во нашата студија сакавме да ја процениме преваленцата на новодијагностициран дијабетес кај пациентите со акутен коронарен синдром и да го процениме односот меѓу стресхипергликемијата, гликорегулацијата и новодијагностицираниот дијабетес со болничкиот морбидитет и морталитет.

Методи: Ова беше лонгитудинална опсервациска студија, со податоци собрани од болничкиот регистар на пациенти хоспитализирани поради акутен коронарен синдром (СТЕМИ-регистар), во периодот јануари 2015 - април 2017 година на Универзитетската клиника за кардиологија во Скопје, Република Македонија. Ги анализиравме демографските, клиничките и биохемиските варијабли, параметрите на гликемичниот метаболизам и хоспиталниот морбидитет и морталитет. Анализата беше споредбена меѓу пет испитувани групи, а поделбата во групи беше направена врз основа на состојбата на глико-регулираност, со користење еден биохемиски параметар - HgbA1C (гликолизиран хемоглобин), а во зависност од присуството на знаен дијабетес пред акутниот настан: 0 - без ДМ (HgbA1C <5,6\%), 1 - новодијагностициран предијабетес (HgbA1C 5,6-6,5\%), 2 - новодијагностициран дијабетес (HgbA1C $\geq 6,5 \%), 3$ - познат добро контролиран дијабетес $(\mathrm{HgbA} 1 \mathrm{C}<7 \%)$ и 4 - познат лошо контролиран дијабетес (HgbA1C $\geq 7 \%)$.

Резултати: Во анализата без вклучени 860 пациенти (590 мажи и 270 жени). Нарушен гликозен метаболизам беше потврден кај $35 \%$ од пациентите, од кои $9 \%$ беа лица со новодијагностициран дијабетес. Стрес-хипергликемија беше регистрирана кај 27,3\% од пациентите, меѓу кои кај 3,6\% пациенти без дијабетес. Највисоките вредности на стрес-хипергликемија беа регистрирани кај новодијагностициран и познат лошо контролиран дијабетес. Стапката на болнички настани изнесуваше $15 \%$, а стапката на болнички морталитет 5\% и таа беше највисока кај пациентите со новодијагностициран и знаен, но неконтролиран дијабетес. Гликолизираниот хемоглобин, стресхипергликемијата и лошата гликемиска контрола (со хипергликемични епизоди) се издвоија како значајни независни предиктори на болничкиот морбидитет и морталитет кај пациентите со АКС.

Заклучок: Беше регистрирана висока преваленца на новодијагностициран дијабетес кај пациентите со акутен коронарен синдром. Стрес-хипергликемија и неуспехот да се постигне гликемична контрола беа независни предиктори за болничкиот морбидитет и морталитет.

Клучни зборови: акутен коронарен синдром, дијабетес мелитус, ново дијагностициран дијабетес, стрес хипергликемија, болнички морбидитет, болнички морталитет. 